\title{
Evaluating ICT Provision in Selected Communities in South Africa
}

\author{
Patience Ngcobo and ME Herselman \\ Faculty of Information \& Communication Technology, \\ Tshwane University of Technology, South Africa
}

\section{patience.ngcobo@stanlib.com herselmanme@tut.ac.za}

\begin{abstract}
The main focus of this paper is to evaluate the provision of ICT in three rural communities in Kwa-Zulu Natal (KZN) in South Africa to determine how the needs of these communities can be addressed. Both qualitative and quantitative research methodologies were applied to address this focus. Results are compared and recommendations are presented that may best meet the needs of the rural communities.
\end{abstract}

Keywords: Rural communities, Kwa-Zulu Natal, South Africa, ICT provision

\section{Introduction}

Currently the estimated population in South Africa is over 45 million people; of nine provinces of which KZN is regarded as one of the provinces estimated to having the highest percentage (8.8 million - 21\%) of people in the country (STATSAA, 2005). Among the eleven different official languages, Zulu is one of the languages been spoken in KZN. English is recognized as being the language of learning and business.

In 2005, the Central Statistical Service (STATSAA, 2005) conducted survey on ICT infrastructure on all the rural communities in KZN. The results of the survey indicated that most of the rural communities have little or no access to basic ICT infrastructure. The survey shows that only $12 \%$ of the households, compared with $13 \%$ nationally, have access to telephone facilities (STATSAA, 2005). The survey makes was supported by the World Bank (2005, p. 1). No mention of Internet access in these rural communities was made (Goldstuck, 2002; STATSAA, 2005). Thus from the statistical information from the survey, it is clearly evident that the majority of rural communities in KZN are still far away from having access to computers and Internet-related technologies.

According to the World Bank (2005) and supported by Conradie and Jacobs (2003) as well as Herselman and Jacobs (2005), developing countries like South Africa as well as rural areas have

Material published as part of this publication, either on-line or in print, is copyrighted by the Informing Science Institute. Permission to make digital or paper copy of part or all of these works for personal or classroom use is granted without fee provided that the copies are not made or distributed for profit or commercial advantage AND that copies 1) bear this notice in full and 2) give the full citation on the first page. It is permissible to abstract these works so long as credit is given. To copy in all other cases or to republish or to post on a server or to redistribute to lists requires specific permission and payment of a fee. Contact Publisher@InformingScience.org to request redistribution permission. various social problems, which create barriers to people owning and using ICTs.

These problems, amongst others, include illiteracy, cultural barriers, lack of computer skills and technological knowhow, lack of access to computers and computers networks as a result of the digital divide, no Internet access, lack of significant usage opportunities, back- 
ground to increasing information equality and structural information equality. The critical issues or factors therefore which limit access to ICT in most developing countries and rural areas are:

- Illiteracy: In most developing countries there are still a high percentage of uneducated people. South Africa is no exception as illiteracy rates are very high and people, especially the young have to go to school and attend institutions of higher learning to get good education. Illiteracy will be drastically reduced if technical or computer skills are imparted to most members of society. People should not just gain access to computers, but should also learn various computer applications so that they can be employable which will reduce the high unemployment rate in South Africa.

- Cultural Barriers: In some developing countries, there are still some people who are barred from using telecommunications technology due to cultural beliefs. Some have "computer fear" and WSIS (2003, p. 148) states that those who fear computers shrink back because they think it is too difficult to use them or because their first experience with such devices have been too unpleasant. It is possible that some do not use computers because of ignorance or may not be aware of how computers can help them. With regard to the latter, these groups can then be given access to computers either by the public or private sector organisations and can be taught how to use computers and shown how computers can help them. Most literature suggests that young people tend to use computers more than old people, so age can also be a determining factor about who uses computers and who do not.

- Lack of computer skills and technological know-how: This is another problem in most developing areas, especially rural areas of Africa. Computer skills are lacking in some people and this problem can be remedied once telecommunication infrastructures have been established in their areas of residence and in addition to that they get access to computers and computer skills imparted to them by those who have this technical know-how.

- Lack of access to computers and computers networks as a result of the digital divide: The digital divide has created a bridge between rural and urban areas in most parts of the developing world.

- No Internet access: The Internet is a good educational tool but can be expensive for poor members of society to afford in terms of paying for all the monthly connections to the Internet Service Providers (ISPs). World Bank (2005) has already stated that most less developed countries in Africa do not have access to the Internet, which will add to their slow development and this is exacerbated by poor telecommunications infrastructures and low tele-densities. Should people have access to the Internet, they can access a wealth of information from this global service and develop many aspects of their lives.

- Lack of significant usage opportunities: The fact that rural people, who form a large part of the inhabitants of developing countries, have no access to telecommunication technologies and other ICTs deny them the opportunities to interact and familiarise themselves with such devices. This is because such devices are not readily available to them where they are located. On the other hand, it is easier for someone residing in a township to get access to a telephone and a fax machine. South African rural areas with telecentres, can have easy access to ICTs located in the telecentres, if these telecentres are fully functional and without access problems and network cut-offs (Herselman \& Jacobs, 2005, p. 59).

Given the various barriers to ICT access in rural areas, the next section will discuss how these barriers to ICT access in rural areas can be addressed. 


\section{ICT Access in the Rural Communities}

The UNDP, in 2001, introduced the concept of the technology Achievement Index (TAI), which attempts to capture how well a country, is creating and diffusing technology, and building human skills. TAI is not a measure of whether the country is leading in global technology development but focuses on how well the country as whole is participating in the creation and use of technology (UNDP, 2001). TAI has four components: creation of technology (capacity to innovate and creative adaptation), diffusion of recent innovations (e.g. the internet), diffusion of old innovations (such as telephone and electricity) and human skills (indicated by many years of education) (UNDP, 2001). These components reflect the capacity of the nation to participate in technological innovations at the present time.

In discussing the role of ICTs, therefore, we are immediately restricted by a preconception of the role of information in development processes which forces considerations such as quality, delivery and efficiency to take precedence over flexibility, creativity and usability. In short, a narrow focus on the role of information leads to a more limited perception of the potential role of ICTs. According to Ramirez (2003, p. 38), information and communication activities are a fundamental element of any rural development activity. Rural areas are often characterized as informationpoor and information provision has always been a central component of rural development initiatives. The rural poor typically lack access to information vital to their lives and livelihoods (Herselman \& Jacobs, 2005, p. 57). Building upon the concept of knowledge gaps and information problems, Ramirez (2003) is proposing a typology (Figure 1) of information used by the rural poor to prioritize their livelihood activities and investment decisions more effectively.

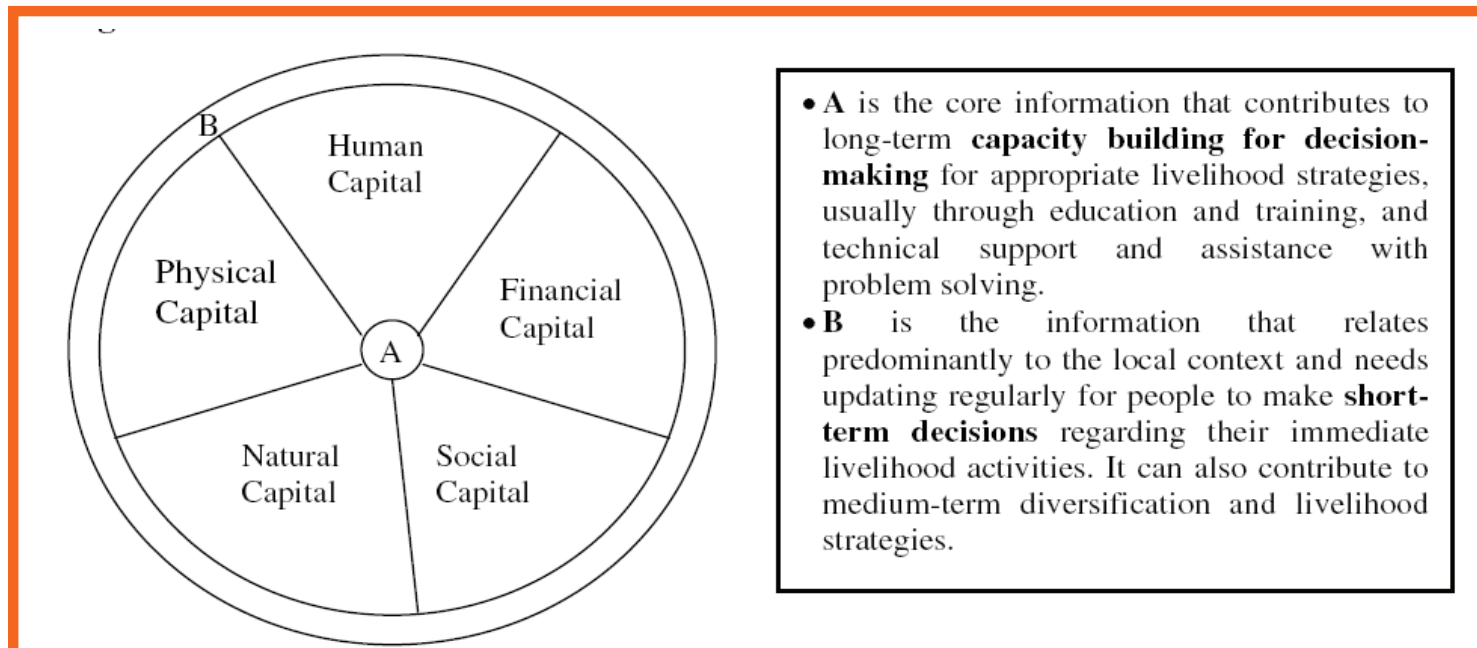

Figure 1: Livelihood Information Wheel (Source: Ramirez, 2003)

In Figure 1, Type A represents information for long-term capacity building involving education, training and technical support appropriate for the livelihood development of individuals or groups. The provision of such information has been a key focus of agricultural extension, health and education initiatives over the years and essentially contributes to the enhancement of knowledge. It also improves understanding of systems and processes, which might affect the way assets are used in the longer term, and assists in the planning of livelihood strategies that effectively insure against stresses and shocks. Type B represents information for short-term decision-making that is used to maximize the potential of a particular asset at any one time, reduce vulnerability to 
shocks and respond to immediate needs. The poor typically lack information about markets for their produce, let alone information about alternative income-generating opportunities. Type B information would also include news relating to the weather and rural services (Ramirez, 2003).

The potential of using ICTs to promote rural development lies partly in increasing market efficiency through addressing information gaps and blockages (Conradie \& Jacobs, 2003), but also in informing and strengthening the decision-making capacity of the rural poor and institutions that to represent them, and in particular, by improving transparency, accountability and administrative efficiency of rural institutions of governance, promoting participation of the poor in decisionmaking processes and improving the efficiency and responsiveness of rural service delivery (Herselman, and Jacobs, 2005; Killick, 2000).

South Africa is a lower middle-income developing country, which, at the turn of the millennium, finds itself at the intersection of many forces of change. At the local level, entrenching democracy, growing the economy and eradicating poverty are some of South Africa's highest priorities. At a global level, South Africa is one of many countries seeking to optimise participation in global markets and successfully integrate new and emerging technologies into society (WSIS, 2003; Zinn, 2000).

The rhetoric of the information society is common today: It is constantly told that this is the era of new technology, where information has become the new currency. The development of an Information Society depends critically on access to information resources, the capacity to use them responsibly, and this can shape life through the use of information (Conradie, Morris, \& Jacobs, 2003; Zinn, 2000).

There has obviously been a new emphasis on the importance of information and it seems set to continue. Perhaps the best opinion to take is that of former Minister of Communications Jay Naidoo (Naidoo, 2005) who argues that Information Society is not an impossible dream, neither is it a sophisticated nicety (it is fundamental to the upliftment of all the disadvantaged people of the world, to ensure that future generations do not suffer the same disadvantages and that the principles of equal opportunities prevail). If the concept of an Information Society is to become a reality, it is imperative that massive investments be made in rural and remote areas.

In order to determine how ICT can benefit the selected rural communities in KZN, some subquestions were addressed to further clarify the main research question. These are:

- What can be done in order to make the use of ICT more effective for rural communities in KZN?

- What ICTs are needed at the community level?

- Which alternative ICT solutions $\backslash$ Models are considered for rural communities in KZN?

Answers to these questions are provided in the findings section.

\section{Research Methodology}

The methodology, which was applied in this study, was quantitative (with the use of a questionnaire), qualitative (with the use of interviews), and a literature study which completes the third part of the triangulation research method (Babbie, 2005, p. 188).

Statistical Analysis System (SAS) and Microsoft Excel were applied to analyse the data as supported by Cooper and Schindler (2003, p. 145). The raw response data was prepared for analysis by tabulating it into an Excel spreadsheet. Thereafter, SAS measurements unit such as frequency percent were used whereby a variable cross comparison was applied (Creswell, 2003, p. 12). 
The analysis of the data firstly dealt with the description of each case (rural community) based on the data collected via the different data collection instruments. Secondly, an analysis was done of similar and different patterns in each sample group. Finally, considering that this research study is composed of the three different case sites, it was necessary to search for patterns in all the samples. This enabled the researchers to develop a strong body of evidence from the samples (Babbie, 2005, p. 167).

KZN was chosen as the target province to collect the data mainly because this province was indicated by both the World Bank (2005 as well as STATSSA (2005) as the province where the density of the population per square metres were the most and where access to technology is also limited. The researcher wanted to determine how ICT can benefit them positively in order to assist government to make the correct decisions about access and sustainability.

The three focus groups chosen for this research study are three small rural towns in southern rural KZN: Ntingwe, Ukomaas and Mtunzini. The sites were carefully selected in consultation with the local community leader and representatives of the respective district in each of the rural communities. "Purposeful sampling" was applied as a strategy to choose smaller towns because they face greater difficulties than larger centres due to their relative population size, smaller economies, and enjoy fewer educational, business and other resources (Schumacher \& McMillan, 1993, p. 175).

Interviews of these three research groups were facilitated by the use of questionnaires developed based on the literature reviews of ICT access as well as demographic profiles of these three rural communities. Data collection was done through both primary and secondary sources. Primary data sources included key informants/participants for each rural community. Secondary data covered different sources such as literature reviews and provided an essential preparation platform for the interviews. Secondary data helped to cross-check official iinformation, learn about major events and technical details, also supporting the exploration of particular responses during interviews.

Table 1 summarizes the locations, period of research as well as the data sources that were applied.

Table 1: Summary of data-gathering process in each of Rural Community in KZN

\begin{tabular}{|c|c|c|c|}
\hline \multicolumn{4}{|c|}{ RESEARCH SAMPLE: (186) } \\
\hline $\begin{array}{l}\text { LOCATION OF } \\
\text { THE STUDY }\end{array}$ & $\begin{array}{l}\text { Ntingwe } \\
\text { Rural Community }\end{array}$ & $\begin{array}{l}\text { Ukomaas } \\
\text { Rural Community }\end{array}$ & $\begin{array}{l}\text { Mtunzini } \\
\text { Rural Community }\end{array}$ \\
\hline $\begin{array}{l}\text { PERIOD OF IN- } \\
\text { VESTIGATION }\end{array}$ & July 2004 - October 2004 & January 2005 - April 2005 & May 2005 - August 2005 \\
\hline DATA SOURCE & $\begin{array}{l}\text { Primary Sources: } \\
\text { Individual Interviews = } 10 \\
\text { Group Interviews = } 15 \\
\text { Completed Question- } \\
\text { naires = } 52 \\
\text { Secondary Sources: } \\
\text { Books } \\
\text { Journals } \\
\text { Magazines } \\
\text { Reports }\end{array}$ & $\begin{array}{l}\text { Primary Sources: } \\
\text { Individual Interviews = } 12 \\
\text { Group Interviews= } 28 \\
\text { Completed Question- } \\
\text { naires = } 33 \\
\text { Secondary Sources: } \\
\text { Books } \\
\text { Journals } \\
\text { Magazines } \\
\text { Reports }\end{array}$ & $\begin{array}{l}\text { Primary Sources: } \\
\text { Individual Interviews = } 5 \\
\text { Group Interviews = } 0 \\
\text { Completed Question- } \\
\text { naires = } 31 \\
\text { Secondary Sources: } \\
\text { Books } \\
\text { Journals } \\
\text { Magazines } \\
\text { Reports }\end{array}$ \\
\hline $\begin{array}{l}\text { TOTAL } \\
\text { NUMBER }\end{array}$ & 77 & 73 & 36 \\
\hline
\end{tabular}




\section{Demographic Profiles of the Rural Communities}

Ntingwe, Ukomaas and, Mtunzini are small rural communities and the total area of these rural communities is less than 120 square kilometres. These rural communities are about $35 \mathrm{~km}$ in distance apart from each other. Most of the regions in these rural communities are mainly mountainous and hilly (STATSAA, 2005).

Based on the census data from 2005, the estimated population of these three rural populations combined is less than 400,000 inhabitants (STATSAA, 2005). About $45.7 \%$ of the population consists of children under the age of 15 . The average household size is $4-6$ persons and nearly $75 \%$ of the households are headed by women (STATSAA, 2005).

Living conditions in these three rural communities are poor. The majority of the houses are without electricity, piped water and sanitation. Only about $5 \%$ of the houses have access to electricity, and $15.3 \%$ of houses have access to piped water (STATSAA, 2005). More than $60 \%$ of the populations in these three rural communities are illiterate. More than half the male population is literate in contrast to little more than $20 \%$ literacy amongst the female population. A large proportion of the population in these three rural communities falls in the range of Grades 8 to 11 and displays educational attainments lower than those of the country as a whole; the education levels are generally low. The unemployment rate is high, particularly amongst the Ukomaas rural community, while those who are working are in low-level jobs (STATSAA, 2005).

\section{Findings from the Research Analysis}

The fieldwork for the three rural communities took place in KZN during the period July 2004 to August 2005. A total of 240 questionnaires ( 80 per group) were sent out to the three rural communities consisting of a combined total of 186 participants. Of the total 240 questionnaires, 116 completed questionnaires were received of which 33 from Ukomaas rural community; 52 from Ntingwe and the remainder 31 from Mtunzini rural community.

Approximately 70 people from a total of 186 participants from the three rural communities in KZN were interviewed during face-to-face interviews during the same period. Individual interviews from Ntingwe, Ukomaas, and Mtunzini communities are 10, 12 and 5 respectively. With the group interviews, there were 15 participants from Ntingwe, 28 from Ukomaas and none from Mtunzini rural community.

Care has been taken to ensure that a range of different people from different backgrounds across the three study groups have been interviewed, including: community leaders; teachers; nurses; elderly people; business people; students; and other literate community members who could provide valuable inputs.

The three research focused groups were defined as people from rural communities who have little or no knowledge of ICT.

More than half of the respondents were between the ages of 31 to 50 , while $3.8 \%$ were below 30 years of age. The remaining respondents were more than 51 years of age. The mean age of the respondents was 39.6 years, which signified that the respondents and communities was mainly middle-aged people.

The educational background of the three rural communities was spread more or less equally across the spectrum right up to the secondary school.

The respondents were mainly farmers and housewives with a representation of $5.1 \%$ and $16.8 \%$, respectively. Public workers, drivers and local municipality workers, each comprised of more than $2.5 \%$ of the respondents. 
The mean income of the respondents was R2340.00 (\$310 USD) per month. Tables $2 \mathrm{a}$ and 2b summarize the main questionnaire results. Table $2 \mathrm{~b}$ has multiple rows per research questions. The column labelled Factor contains all the issues addressed by the main and the sub-research questions, which were rated by the respondents. Each Factor is coded V1 to V22.

These codes were used by the SAS System to compute the frequency and correlation distribution (frequency table) for each factor represented in the table. In the frequency distribution, the following factors were rated as most important:

- Stimulate positive attitude toward change: Most(95\%) of the respondents strongly felt that a positive attitude toward change is an extremely important factor in rural ICT deployment process. The highest percentage rated this factor (95\%) as extremely important.

- Ensure technologies are appropriate: This factor was rated as important by $75 \%$ of respondents.

- Combine traditional and modern technologies: The respondents fully agreed that combining traditional and modern technologies will not only preserve the culture but also served as encouragement to tolerate changes. This factor was rated as extremely important by $70 \%$ of respondents.

- Empower rural poor people and communities to lead their own development: This factor was rated as extremely important by $98 \%$ of respondents and the reason given was that of self-sustainability.

- $\quad$ Recognize that technology is important, but must be appropriate - and sustainable for poor people: $87 \%$ of the respondents rated this as extremely important because it is believed that appropriate technology will accelerate the rate of rural development.

Table 2a: Research Questions

Research Questions

How can ICT benefit Communities in Rural KZN?

What can be done in order to make the use of ICT more effective for rural communities in KZN?

What ICTs are needed at the community level?

Which alternative ICT solutions IModels are considered effective and efficient for rural communities in KZN? 
Table 2b: Questionnaire results

\begin{tabular}{|c|c|c|c|c|c|c|c|}
\hline \multirow[t]{2}{*}{ 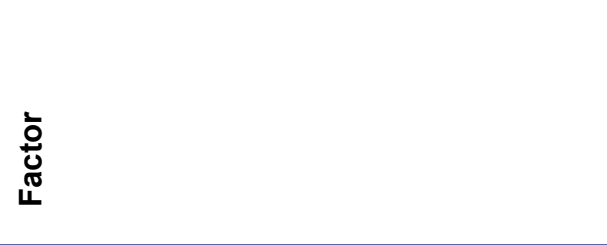 } & \multirow[t]{2}{*}{ 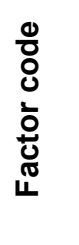 } & \multirow[t]{2}{*}{ 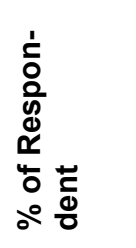 } & 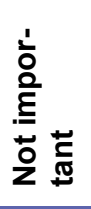 & $\begin{array}{l}\frac{0}{\pi} \\
\frac{\pi}{0} \\
\frac{0}{0} \\
\Sigma\end{array}$ & 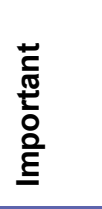 & 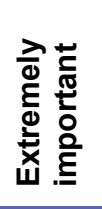 & \multirow[t]{2}{*}{ 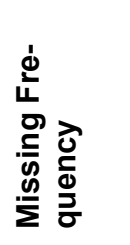 } \\
\hline & & & 1 & 2 & 3 & 4 & \\
\hline Stimulate positive attitude toward change & V1 & $95 \%$ & & & & $\sqrt{ }$ & 2 \\
\hline $\begin{array}{l}\text { Engage with civil society and the private } \\
\text { sector for provision of infrastructure }\end{array}$ & V2 & $53 \%$ & & $\sqrt{ }$ & & & 5 \\
\hline Ensure technologies are appropriate & V3 & $75.8 \%$ & & & & $\sqrt{ }$ & 1 \\
\hline $\begin{array}{l}\text { Combine traditional and modern tech- } \\
\text { nologies }\end{array}$ & V4 & $70.8 \%$ & & & & $\sqrt{ }$ & 7 \\
\hline $\begin{array}{l}\text { Empower rural poor people and communi- } \\
\text { ties to lead their own development }\end{array}$ & V5 & $98 \%$ & & & & $\sqrt{ }$ & 4 \\
\hline $\begin{array}{l}\text { Recognize that technology is important, } \\
\text { but must be appropriate - and sustainable } \\
\text { for poor people }\end{array}$ & V6 & $87 \%$ & & & $\sqrt{ }$ & & 2 \\
\hline Improved Service Delivery & V9 & $55.8 \%$ & & & & $\sqrt{ }$ & 11 \\
\hline $\begin{array}{l}\text { Develop in-come generating activi- } \\
\text { ties/programmes }\end{array}$ & V10 & $70.8 \%$ & & & & $\sqrt{ }$ & 7 \\
\hline $\begin{array}{l}\text { Encourage foundations and donors to } \\
\text { invest in developing ICTs' multimedia } \\
\text { capabilities to support the needs of com- } \\
\text { munities with strong oral traditions }\end{array}$ & V11 & $79 \%$ & & & & $\sqrt{ }$ & 5 \\
\hline $\begin{array}{l}\text { Promote open access to low cost tech- } \\
\text { nologies }\end{array}$ & V12 & $99.5 \%$ & & & & $\sqrt{ }$ & 1 \\
\hline $\begin{array}{l}\text { Envision ICTs from the perspective of the } \\
\text { users and through their active participa- } \\
\text { tion }\end{array}$ & V13 & $74 \%$ & & & & $\sqrt{ }$ & 4 \\
\hline $\begin{array}{l}\text { Empower the citizens to access informa- } \\
\text { tion and knowledge }\end{array}$ & V14 & $65.8 \%$ & & & & $\sqrt{ }$ & 8 \\
\hline $\begin{array}{l}\text { Have access to telecommunication infra- } \\
\text { structures }\end{array}$ & V15 & $80 \%$ & & & & $\sqrt{ }$ & 6 \\
\hline $\begin{array}{l}\text { Develop appropriate technologies for rural } \\
\text { connectivity and information processing }\end{array}$ & V16 & $96.6 \%$ & & & & $\sqrt{ }$ & 3 \\
\hline $\begin{array}{l}\text { Pro-Poor Rural and Universal Access } \\
\text { Policies }\end{array}$ & V18 & $83.3 \%$ & & & & $\sqrt{ }$ & 4 \\
\hline $\begin{array}{l}\text { Design citizen-centric services and de- } \\
\text { pendable service delivery mechanisms }\end{array}$ & V20 & $95.8 \%$ & & & & $\sqrt{ }$ & 1 \\
\hline $\begin{array}{l}\text { Focus on convergence - building on exist- } \\
\text { ing ICT projects converge with local } \\
\text { schools, local libraries, local development } \\
\text { projects and local social organizations }\end{array}$ & V21 & $87.5 \%$ & & & & $\sqrt{ }$ & 3 \\
\hline $\begin{array}{l}\text { Develop culturally sensitive networking } \\
\text { that can build and promote capacity build- } \\
\text { ing and skills development in rural areas }\end{array}$ & V22 & $97.3 \%$ & & & & $\sqrt{ }$ & 4 \\
\hline
\end{tabular}


After the questionnaire results were analysed, interviews were conducted. All the interviews were conducted in Zulu and for the purpose of this research study, were translated into English by the researcher herself. The interviews typically lasted about 1 hour 30 minutes. All interviews were transcribed in 'word' format (in Zulu) and extensive notes were also taken during the fieldwork. The interview sessions began with the introduction of the research objectives and the key expected results.

In general, the individual interviews were aimed at obtaining a description of the demographic; educational and employment background, and to gain an understanding of their expectations regarding quality of ICT services within the local community.

In the three rural communities investigated, a total of 70 participants out of the 186 participants were interviewed. Some of the responses from the interviewees are indicated in Table 3.

Table: 3: Responses from the interviewees

\begin{tabular}{|c|c|}
\hline The Research Questions & $\begin{array}{l}\text { Responses from some of the research participants from the three } \\
\text { rural communities in KZN }\end{array}$ \\
\hline $\begin{array}{l}\text { How can ICT benefit Commu- } \\
\text { nities in Rural KZN? }\end{array}$ & $\begin{array}{l}\text { "ICT is something very new to some of us, if it can improve the level of } \\
\text { service delivery, then we will be happy" [Ukomaas rural community } \\
\text { member]. } \\
\text { "Will it be able to allow us to preserve our culture without losing track of } \\
\text { our root?" } \\
\text { [Mtunzini rural community member]. } \\
\text { "Raise ICT awareness and foster community interest; setup ICT centre } \\
\text { to train people in the use of ICT particularly young people" [Ukomaas } \\
\text { rural community member]. } \\
\text { "How can a poor person like me be able to afford or have an access to } \\
\text { it if I don't even know how?" [Ntingwe rural community member]. }\end{array}$ \\
\hline $\begin{array}{l}\text { What can be done in order to } \\
\text { make the use of ICT more } \\
\text { effective for rural communities } \\
\text { in KZN? }\end{array}$ & $\begin{array}{l}\text { "Revise telecommunication pricing as a way to reduce the rural isola- } \\
\text { tion" [Ntingwe rural community member]. } \\
\text { "Raise awareness for change in the educational culture through use of } \\
\text { tools based on ICT" [Mtunzini rural community member]. } \\
\text { "...Prepare younger generation in ICT skills as an opportunity to gain } \\
\text { employment" } \\
\text { [Ukomaas rural community member]. } \\
\text { "Introduce ICT training programmes directly related to local community } \\
\text { needs" } \\
\text { [Ntingwe rural community member]. } \\
\text { "Design ICT policies that contribute to the universal access to informa- } \\
\text { tion" } \\
\text { [Ukomaas rural community member]. }\end{array}$ \\
\hline $\begin{array}{l}\text { What ICT are needed at the } \\
\text { community level? }\end{array}$ & $\begin{array}{l}\text { "ICT should be deployed in such a way to encourage /stimulate people } \\
\text { to have positive attitude to accept it" [Response from group interview } \\
\text { member at Ntingwe rural community]. } \\
\text { "An improvement in service delivery is a better life for all" [Ukomaas } \\
\text { rural community member]. } \\
\text { "...encourage youths to participate in ICT related-activities" [Mtunzini } \\
\text { rural community member]. }\end{array}$ \\
\hline
\end{tabular}




\begin{tabular}{|l|l|}
\hline $\begin{array}{l}\text { Which alternative ICT solu- } \\
\text { tionslModels are considered? }\end{array}$ & $\begin{array}{l}\text { "Setup ICT programmes to train community of the benefits of ICT" } \\
\text { [Ukomaas rural community member]. } \\
\text { "Introduce ICT education to school children at an early stage" [Uko- } \\
\text { maas rural community member]. } \\
\text { "I don't know "- Response from two respondents at the group interview } \\
\text { from Ukomaas rural community. } \\
\text { "..We need an ICT model that should help maximize the efficacy of } \\
\text { ICTs in poverty reduction in our community" [response from the com- } \\
\text { munity leader at Mtunzini rural community]. }\end{array}$ \\
\hline
\end{tabular}

It is evident from the various responses from the three rural communities that most of the respondents strongly felt that ICT deployment in their community can enhance and uplift the quality of their lives.

These findings are further supported by various literature reviews from different authors. For example, the literature study by D'Orville (2000, p. 97) when he states that ICT can be used to stimulate economic growth and human development but for this to be true ICT must be looked at with new eyes and in innovative ways. To meet this challenge the process of spreading ICT must become more responsive to the needs of the rural context.

\section{Conclusion and Recommendations}

It is argued that ICT-related initiatives can only contribute to human development if the implementation of these initiatives is aligned with the development programmes of the rural communities within the social context (Ramirez, 2003).

The challenges discussed in previous sections affirm that "There is no magic 'digital wand' that would overcome the scourge of poverty overnight."

ICT for development should recognize the unfulfilled right to access information and support participatory decision-making at the local level for all sectors of the population, including elders, females and the geographically isolated. The study identified the impediments blocking these rural KZN from accessing meaningful information and new ICT services as: lack of resources (by the communities); lack of knowledge and skills to utilize new ICTs; no local language content in the Internet; lack of fixed-line telecommunications infrastructure and/or electricity in some localities; and finally, static government websites (information resources).

The study advocates the resolution of these problems along three strands: technological, institutional and policy-based. It is hoped that this study will add value particularly to the disadvantaged rural communities that was used as samples in this research study and to the rest of the rural communities across South Africa.

Finally, the study emphasizes the citizens' inalienable right to access (public) information. The study firmly maintains that, in order for the rural communities of KZN to attain an "information society" that truly belongs to all, information - that empowering intangible - must be provided and constantly improved to realize this dream. All citizens (deep and remote rural) must thus be allowed access to that information by the next golden jubilee of the country's democracy. 


\section{References}

Babbie, E. (2005). The practice of social research. Belmont, California: Wadsworth.

Creswell, J.W. (2003). Social research. London: Sage Publications.

Conradie, D.P. \& Jacobs, S.J. (2003). Challenges encountered when using ICTs in support of development in rural African communities. Engineering Management, February, 30-33.

Conradie D.P., Morris, C. \& Jacobs S.J. (2003). Using information and communication technologies (ICTs) for deep rural development in South Africa. Communication, 29 (1 \& 2), 199-217.

Cooper, D.R. \& Schindler, P.S. (2003). Business research methods ( $8^{\text {th }}$ ed.). New York: McGrawHill/Irwin.

D’Orville, H. (2000). Knowledge and information - New levers for development and prosperity. Choice Magazine, June, 23-55.

Goldstuck, A. (2002). The Goldstuck report: Internet access in South Africa. [Online]. Retrieved 12/07/2006 from http://www.theworx.biz/access02.html

Herselman, M.E. \& Jacobs, S.J. (2005). An ICT-hub model for rural communities. International Journal of Education and Development using ICT, 1(3), 57-93.

Killick, T. (2000). IFAD Report: Economic change and welfare of the rural poor. IFAD's Rural Poverty, October 2000.

Naidoo, K. (2005). Civil society. Proceedings of the Sangonet Conference, 103, March 2005, Fourways, Johannesburg.

Ramirez, R. (2003). Communication: A meeting ground for sustainable development. Advancing telecommunications for rural development through a participatory communication approach. Rome: FAO.

Schumacher, S. \& McMillan, J.H. (1993). Research in education: A conceptual introduction. New York: Harper Collins College Publishers.

STATSAA: (2005). Census 2005 database. [Online] .Retrieved 03/09/2006 from http://www.statistics.gov.za

UNDP. (2001). Digital opportunity initiative: Creating development dynamic. New York, June 2001. [Online] Retrieved 07/07/2006 from http://www.opt-init.org/framework/

World Bank. (2005). Draft report: Financing information and communication infrastructure needs in the developing world February [Online] Retrieved 19/02/2006 from http://info.worldbank.org/ict/

WSIS. 2003. Community access and how to measure it. [Online]. Retrieved 15/07/2006 from http://www.itu.int/wsis/basic/basic.01.htm

Zinn, S. 2000. Information literacy in South Africa: Making strides with information and communication technology. IASL Newsletter, 29(4), $123-179$. 


\section{Biographies}

Mrs Patience Ngcobo was a Masters Degree student who completed her studies in 2006 in the Faculty of ICT at the Tshwane University of Technology. Currently she is pursuing a MBA study and is also full time employed at Stanlib in South Africa. Feedback from this study she conducted in KZN in South Africa was used by government to improve service delivery in the region especially to the rural areas.

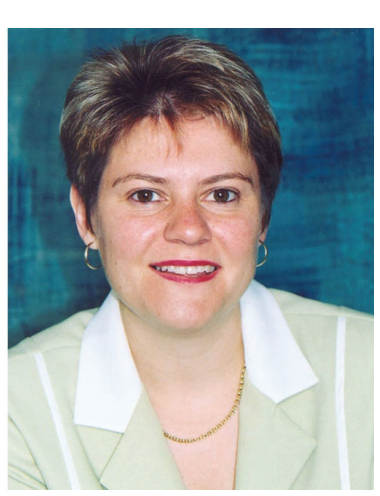

Prof Marlien Herselman is an Associate Research Professor of the Faculty of Information and Communication Technology. In this capacity she assists lecturers and postgraduate students in research projects, National Research Foundation (NRF) projects, in writing research articles, and in other research-related activities. She obtained her $\mathrm{PhD}$ at the University of Pretoria in 1999. Her PhD studies focused on the use of computer games. She is currently busy with research on Technology assessment in rural communities regarding ehealth in South Africa with a National Research Foundation funded project.

from 2003 to 2005 .

She was also chairperson of the Faculty Quality Implementation Team

In 2005 she received the prize as Women Researcher of the Year 2004 at Tshwane University of Technology. 